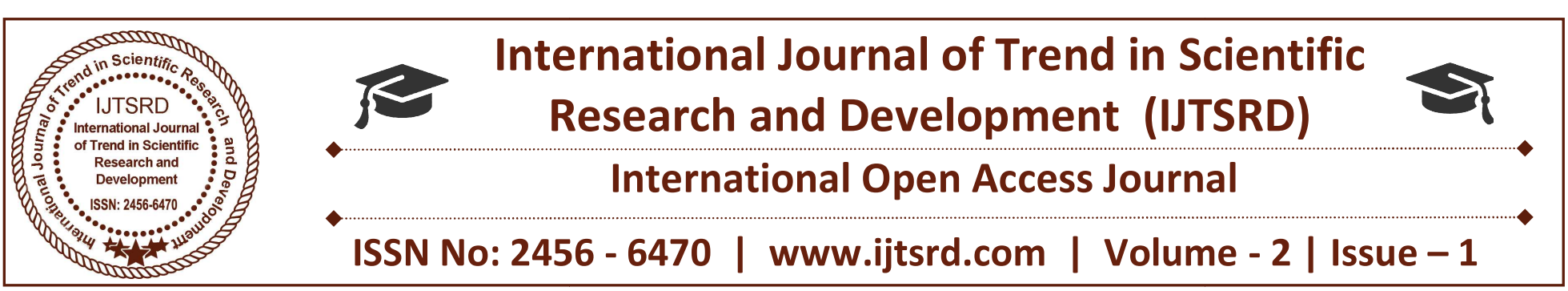

\title{
Investments in Corporate Social Responsibility and Its Effect on Financial Performance of Commercial Banks in Ethiopia
}

\author{
Dr. Uvaneswaran .S .M \\ Professor Department of Accounting \& Finance, \\ College of Business \& Economics, Wollo University, \\ P.B No:1145, Dessie, Amahara Region, Ethiopia
}

\author{
Mr. Hussien Fentaw Ayele \\ Lecturer, Department of Accounting \& Finance, \\ College of Business \& Economics, Wollo University, \\ P.B No:1145, Dessie, Amahara Region, Ethiopia
}

\begin{abstract}
Corporate social responsibility (CSR) refer to Strategies Corporation or corporate conduct their business in a way that is ethical, society friendly and beneficial to environmental and community in terms of development. CSR activities have been associated with financial performance of organizations but this area has not been well touched by the researchers in Ethiopia particularly in banking business. The basic purpose of this research is to identify the effects of corporate social responsibility investment activities on financial performance of commercial banks in Ethiopia. Further, Financial performance was measured by net profits before taxes which are obtained from audited statements of comprehensive income from the year 2012 to 2016 and investment in CSR was measured using monetary spending on social activities in education, health and environmental aspects. To chase the above reason, 11 commercial banks are selected based on the availability of data on investments in Social activities from the total of 17 banks. This paper provides the impact on Investment in Social activities towards the growth of financial performance in the Ethiopian banking sector.
\end{abstract}

Key words: CSR, financial performance, commercial banks, Net profits before tax

JEL Classification System; M14, M40

\section{INTRODUCTION}

\subsection{Background of the Study}

Corporate social responsibility is one of the newest management strategies where companies try to create a positive impact on society while doing business. Carol (2003) defines corporate social responsibility (CSR), corporate responsibility, corporate citizenship, responsible business, sustainable responsible business or corporate social performance as a sense of responsibility towards the community and environment (both ecological and social) in which it operates. Companies express this citizenship through their waste and pollution reduction processes, by contributing educational and social programs, and by earning adequate returns on the employed resources.

The present-day CSR (also called corporate responsibility, corporate citizenship, responsible business and corporate social opportunity) covers the relationship between the corporations and the society within which they interact (Werther \& Chandler, 2010). It is a concept whereby business organizations consider the interest of society by taking responsibility for the impact of their activities on customers, suppliers, employees, shareholders, communities and other stakeholders as well as their environment. This obligation shows that the organizations have to comply with legislation and voluntarily take initiatives to improve the well-being of their internal and external stakeholders as well as for the local community and society at large. 
In today's world, running a business is no longer just considering how to make profits, but also includes bearing certain responsibilities in the society. Such issues further extend the companies' view from a business level to a community or society level. This also reflects a fact that consumers' values are changing in the society, companies have to adapt to the changing value of consumers and seek for long-term relationship with consumers so as to survive and grow (Yuen et al., 2007).

The banking sector in Ethiopia is composed of 16 private and 1 state-owned commercial banks, one stateowned development bank, 17 private and one stateowned insurance companies, more than 30 microfinance institutions, and few emerging leasefinance companies. Under the supervision of the NBE, the Ethiopian banking sector is rapidly growing, developing its outreach and exhibiting strong financial soundness (NBE, 2016).

As Yeung (2011) had clearly mentioned that no matter what kinds of countries, what kinds of culture, and what kinds of banking products and investors, banks need to be responsible for their customers in a socially responsible way. As a socially responsible bank, it not only executes lawful banking practice, but also practices wisely and prudentially with close supervision of transactions for providing customer confidence under prosperous and glooming economic conditions.

\subsection{Statement of the Problem}

Ethiopia is one of the developing countries; the philosophy of corporate social responsibility is not well developed. Corporate social responsibility of banks in Ethiopia is untouched part. The National Bank of Ethiopia (NBE) has mainly play role of regulation on the financial performance of commercial banks as pertain to the rules and regulations set by the country so as to protect the public and develop confidence on the services provided by banks. However, the need for CSR requires more for the banks to pay special attention towards integration of social and environmental concerns in their business operations to attain a sustainable profit. Poverty in the country, illiteracy, poor infrastructure, bad road network and environmental pollution are possible issues that necessitate the need for organizations to play active role in the society in order to address the problems. There are huge costs involved in engaging in social responsibility, which may affect the performance of organizations.
Some researches related to corporate social responsibility have been conducted but none of the studies looked at the impact that CSR has on a firm's financial performance; hence, there exists a research gap. Abdulhamid (2013) carried out an assessment on Corporate Social Responsibility Practices and Determinants: a comparative Study Conducted in the Ethiopian Leather Industry and Yeneneh (2015) conducted a research on the practice and role of private commercial banks on corporate social responsibility in Ethiopia. However, to the best of the researcher knowledge there are no studies that link CSR's effect on banks financial performance leaving this area plausible for research. This study is therefore aiming at filling this gap by interrogating the question: "Does investing in corporate social responsibility activities have an effect on the financial performance of commercial banks in Ethiopia?"

\subsection{Objectives of the study}

The objective of the study is to examine the investment in corporate social responsibility activities and its effect on financial performance of the commercial banks in Ethiopia. It is measured on CSR expenditure by grouping the CSR attributes as health, education and environmental aspects.

\subsection{Significance of the study}

There is a significant need for the study of corporate social responsibility in the Ethiopian banking sector because academics, governments, and business persons know little about the impact of CSR on financial performance in developing nations and specifically in Ethiopia. The study findings will help the policy makers in the financial sector particularly in the banking industry to gain insight into the financial motivations that determine which CSR activities that banks engage in. It will help in developing guidelines that commercial banks may adopt in their CSR efforts. Planners and implementers of bank strategies can possibly adopt the study findings and recommendations thereof in formulating CSR strategies for their banks so as to be competent enough in the banking industry.

\subsection{Scope of the Study}

This study examines the investment effect of CSR on financial performance of commercial banks in Ethiopia. The study covers all 11 commercial banks in Ethiopia that incorporate CSR in their activities and the time 
frame covers for the period of five years from 2012 to 2016.

\section{LITERATURE REVIEW}

Odetayo, Adeyemi and Sajuyigbe (2014) had conducted research under the title " Impact of Corporate Social Responsibility on Profitability of Nigeria Banks " with the objective of examines the effect of expenditure on corporate social responsibility on profitability of Nigerian banks and to investigate into whether or not there is a significant relationship between corporate social responsibility and profitability of banks. The methodology employed was used secondary data that were obtained from the financial statement of six sample banks quoted in Nigerian Stock Exchange. They had found the result of regression analysis showed that there is a significant relationship between expenditure on corporate social responsibility and profitability of six sampled banks. This study conforms to the stakeholders' theory that explained organizations have responsibility to various groups of company stakeholders both internal and external and not just the owners of the company.

Kipruto (2014) had conducted research under the title "The effect of corporate social responsibility on financial performance of commercial banks in Kenya" The study intended to determine the effect that CSR has on financial performance of commercial banks in Kenya that had invested in CSR from the year 2009 to 2013. A non probabilistic sampling design was used since the data was only from those firms that have incorporated CSR in their activities. The study used secondary data for analysis which included data from the company's annual reports to shareholders. The researcher used cross-sectional research design and a regression model and found that CSR has a positive and significant effect on financial performance of commercial banks. This study concluded that CSR is essential for the success of commercial banks since it helps to improve financial performance.

Okoth (2012) found out that CSR was good for the financial performance of large and medium size banks and had no effect on the ROA of small banks. The researcher realized that CSR had a positive and significant effect on ROA and ROE for all commercial banks when aggregated. However, when classified on the basis of market size, the study revealed that CSR improved financial performance of large and medium size banks while the effect on ROA of small banks was insignificant. This study concluded that CSR had a positive effect on financial performance of large and medium size banks and no significant effect on the financial performance of small banks. The researcher concluded that it was not in the interest of shareholders for small banks to engage in CSR activities as doing so could only drain their wealth without any return.

Arya (2009) supports the idea that CSR has a positive correlation with profitability through a study which sought to investigate the manner in which CSR affects share price. The study included companies around Soweto Township which had embraced social responsibility with short-term and long-term strategies in place. The studies conducted during the 10 year period preceding 2005 found out that $80 \%$ of company's recorded sharp increases in profitability attributed to long-term strategies. The short-term strategies did not affect performance in a significant way.

A closer examination of these studies reveals variations on data sources, measures used on both dependent and independent variables and control variables. The researchers have not been conclusive as to what is the relationship between corporate social responsibility and financial performance. The aforementioned empirical studies have demonstrated that there is a link between CSR and financial performance. Most of the early studies attempting to identify the relationship between CSR and financial performance have focused on subjective techniques to measure CSR. These studies have not, however, demonstrated how a firm's financial performance would be affected by investing in CSR activities.

\section{MATERIALS AND METHODS}

\subsection{Research Design}

This study employed descriptive research design. The study utilized time series data that involve corporate social responsibility expenditure and net profit before tax of Ethiopian commercial banks which covered a period of five years $(2012-2016)$.

\subsection{Data sources and collection methods}

This study exclusively relied on secondary data. Quantitative data was obtained from audited financial statements of commercial banks participating in the study for the period of five years from 2012 to 2016. The mentioned data was accessed from the websites of the sample commercial banks. The nature of data used included statement of financial position, statement of 
International Journal of Trend in Scientific Research and Development (IJTSRD) ISSN: 2456-6470

comprehensive income and annual reports to stakeholders. Some commercial banks which were included in the study had not full financial operation before year 2012, for the study used five years of data starting from year 2012 to 2016.

\subsection{Sampling design and techniques}

The study targeted all commercial banks in Ethiopia that had invested in CSR activities from the year 20012 to 2016. A non-probabilistic sampling design was used since the data is only from those banks that have incorporated CSR in their activities from the year 2012 to 2016. Investment in CSR activities was tested against net profits before tax for the same period.

\subsection{Data analysis and presentation}

Collected data was analyzed using the Statistical Package for Social Sciences (SPSS) Version 20 and STATA 12 to determine the effect of bank's CSR investment on financial performance. Data analysis captured both descriptive statistics and econometrics. Descriptive statistics comprised sum, percentages and mean by using the Statistical Package for Social Sciences (SPSS) Version 20. Econometrics constituted correlation and multiple regression analyses. Multiple regression analysis was used to determine the effect of CSR expenditure on banks' financial performance at $5 \%$ level of significance, and correlation analysis was done to determine the strength of relationship or to detect any chance of multicollinarity among the study variables. The results of the analyses were presented in form of tables by using STATA 12.

\section{RESULTS AND DISCUSSION}

The analysis is based on the findings on profit before tax for five years compared to the amount used in CSR activities. The targeted 17 commercial banks out of data for this research, so it is based on the response rate of $65 \%(n=11)$. This presents descriptive statistics, correlation analysis, and regression analysis. It concludes with a discussion and Interpretation of research findings.

\subsection{Nature of NPBT and CSR}

Table 1 shows the profitability for the banks under study for a period of five years compared to the amount spent on CSR activities. From the above table, NPBT for all banks under study increased each year for the whole period whereas the amount spent on CSR activities increased for the consecutive four years, but it decreased on the fifth year. NPBT and the amount spent for CSR for all banks in 2012 was the least compared to the following years. The year 2015 was the highest CSR expenditure period followed by 2014 and 2016 respectively. In 2012, the bank that spent the largest amount on CSR activities had the highest profit. Although Awash International Bank spent the highest amount on CSR activities for five years, it made less profit than Dashen Bank Share Company which spent the lesser amount for CSR. In contrast, Addis International Bank Share Company spent the least amount for CSR from all the sample banks for five years and generated the least amount of profit. On the other hand Awash International Bank, which spent almost double amount for CSR in comparison with Dashen Bank Share Company, generated about $84 \%$ of Dashen Bank's NPBT.

\section{Table 1: NPBT and CSR activities for Five Years (Amount in Millions of ETB currency)}

\begin{tabular}{|c|c|c|c|c|c|c|c|c|c|c|c|c|c|c|}
\hline \multicolumn{11}{|c|}{ Years } & \multicolumn{2}{|c|}{ Mean } & \multicolumn{2}{|c|}{ Sum } \\
\hline & 2012 & & 2013 & & 2014 & & 2015 & & 2016 & & & & & \\
\hline Banks & NPBT & $\begin{array}{c}\mathbf{C S} \\
\mathbf{R} \\
\end{array}$ & NPBT & $\begin{array}{c}\mathbf{C S} \\
\mathbf{R} \\
\end{array}$ & NPBT & $\begin{array}{c}\text { CS } \\
\mathbf{R} \\
\end{array}$ & NPBT & $\begin{array}{c}\text { CS } \\
\mathbf{R} \\
\end{array}$ & NPBT & $\begin{array}{c}\text { CS } \\
\mathbf{R} \\
\end{array}$ & NPBT & $\begin{array}{c}\text { CS } \\
\mathbf{R} \\
\end{array}$ & NPBT & CSR \\
\hline $\mathrm{AB}$ & 31.38 & - & 50.87 & - & 75.68 & - & 168.01 & 1 & 191.96 & - & 103.58 & 0.2 & 517.9 & 1 \\
\hline ADIB & 9.29 & - & 37.06 & 0 & 60.1 & - & 78.35 & 0.05 & 112.76 & 0.08 & 59.51 & 0.03 & 297.56 & 0.13 \\
\hline AIB & 580.13 & 0.16 & 583.02 & 0.06 & 828.81 & 3.63 & 861.22 & 6.03 & 985.98 & 2.5 & 767.83 & 2.48 & $3,839.16$ & 12.38 \\
\hline $\mathrm{BOA}$ & 288.58 & 0.13 & 351.47 & 0.1 & 351.49 & 0.08 & 373.96 & 2.26 & 487.24 & 1 & 370.55 & 0.71 & $1,852.74$ & 3.57 \\
\hline $\mathrm{CBO}$ & 139.77 & 0.01 & 266.96 & 0.02 & 475.85 & 4.03 & 480.99 & 2.24 & 36.95 & 0.06 & 280.1 & 1.27 & $1,400.52$ & 6.36 \\
\hline DB & 893.26 & 0.75 & 812.93 & 1.02 & 957.59 & 0.66 & 963.81 & 2.74 & 950.61 & 1.34 & 915.64 & 1.3 & $4,578.20$ & 6.51 \\
\hline LB & 104.7 & - & 150.6 & - & 127.19 & - & 275.59 & 2 & 349.67 & 0.15 & 201.55 & 0.43 & $1,007.75$ & 2.15 \\
\hline OIB & 65.16 & 0.07 & 102.15 & 0.45 & 204.89 & 0.1 & 293.98 & 0.05 & 325.05 & 0.18 & 198.25 & 0.17 & 991.23 & 0.85 \\
\hline
\end{tabular}


International Journal of Trend in Scientific Research and Development (IJTSRD) ISSN: 2456-6470

\begin{tabular}{|c|c|c|c|c|c|c|c|c|c|c|c|c|c|c|}
\hline \multicolumn{10}{|c|}{ Years } & \multicolumn{10}{c|}{ Mean } & \multicolumn{1}{c|}{ Sum } \\
\hline UB & 406.5 & 0.19 & 374.16 & 0.13 & 361.02 & 0.17 & 358.24 & 0.26 & 428.54 & 0.35 & 385.69 & 0.22 & $1,928.46$ & 1.1 \\
\hline WB & 458.26 & - & 449.67 & 0.01 & 413.79 & - & 452.57 & 2.75 & 478.5 & 0.65 & 450.56 & 0.18 & $2,252.79$ & 3.41 \\
\hline ZB & 123.31 & 0.2 & 123.81 & 0.2 & 164.57 & 0.19 & 200.51 & 0.53 & 270.05 & 0.95 & 176.45 & 0.86 & 882.25 & 2.07 \\
\hline Sum & $\begin{array}{c}\mathbf{3 , 1 0 0 . 3} \\
\mathbf{0}\end{array}$ & $\mathbf{1 . 5}$ & $\mathbf{3 , 3 0 2 . 7}$ & $\mathbf{1 . 9 9}$ & $\mathbf{4 , 0 2 0 . 9}$ & $\mathbf{8 . 8 6}$ & $\mathbf{4 , 5 0 7 . 2}$ & $\mathbf{1 9 . 9}$ & $\mathbf{4 , 6 1 7 . 3}$ & $\mathbf{7 . 2 6}$ & $\mathbf{3 , 9 0 9 . 7}$ & $\mathbf{7 . 8 5}$ & $\mathbf{1 9 , 5 4 8 . 4}$ & $\mathbf{3 9 . 5}$ \\
\hline
\end{tabular}

Source: Research results 2017

\subsection{Share of CSR from NPBT}

Table 2 shows NPBT, CSR and share of CSR from NPBT for the sample banks under study for the period of five years. From the above table, share of CSR from NPBT for all banks showed an increasing trend for the first four years, and it decreased in the last years (2016). Year 2012 recorded the least CSR share followed by year 2013, 2014 and 2016 respectively. In contrast, year 2015 was the highest CSR share which constituted $0.44 \%$ from NPBT. The overall share of CSR from NPBT for the five Years under study was only $0.20 \%$ which was ETB 39.51 million compared to ETB 19,548.4 million of NPBT.

\section{Table 2 :Share of CSR from NPBT for five Years(Amount in Millions of ETB)}

\begin{tabular}{|l|l|l|l|l|l|l|}
\hline Particulars & Years & Total \\
\hline & $\mathbf{2 0 1 2}$ & $\mathbf{2 0 1 3}$ & $\mathbf{2 0 1 4}$ & $\mathbf{2 0 1 5}$ & $\mathbf{2 0 1 6}$ & \\
\hline NPBT & $3,100.30$ & $3,302.70$ & $4,020.90$ & $4,507.20$ & $4,617.30$ & $19,548.40$ \\
\hline CSR & 1.5 & 1.99 & 8.86 & 19.9 & 7.26 & 39.51 \\
\hline $\begin{array}{l}\text { share of CSR } \\
\text { from NPBT }\end{array}$ & $\mathbf{0 . 0 5}$ & $\mathbf{0 . 0 6}$ & $\mathbf{0 . 2 2}$ & $\mathbf{0 . 4 4}$ & $\mathbf{0 . 1 6}$ & $\mathbf{0 . 2}$ \\
\hline
\end{tabular}

Source: Research result, 2017

\subsection{Share of CSR attributes from total CSR}

From the below table 3, we can understand that share of education CSR for the five years held $48 \%$ from the total CSR followed by health and environment which constituted $46 \%$ and $6 \%$ respectively. This means Share of CSR environment activities from total CSR was the least for the five years. On the contrary, education CSR constituted the highest share followed by health CSR. Education CSR held the highest share all the years except the year 2013 which was the highest share period for health CSR activities. The peak seasons for environment CSR activities were year 2012, 2013 and 2016 where as its slack seasons were year 2014 and 2015.

Table 3: Share of CSR attributes from Total CSR ((Amount in Millions of ETB)

\begin{tabular}{|c|c|c|c|c|c|c|c|c|c|c|c|c|}
\hline \multirow{3}{*}{$\begin{array}{l}\text { CSR } \\
\text { Attributes }\end{array}$} & \multicolumn{10}{|c|}{ Years } & \multicolumn{2}{|l|}{ Total } \\
\hline & \multicolumn{2}{|l|}{2012} & \multicolumn{2}{|l|}{2013} & \multicolumn{2}{|l|}{2014} & \multicolumn{2}{|l|}{2015} & \multicolumn{2}{|l|}{2016} & & \\
\hline & Amt* & Share & Amt* & Share & Amt* & Shar & Amt* & Share & Amt* & Share & Amt* & Share \\
\hline Education & 0.64 & 42 & 0.67 & 34 & 4.36 & 49 & 9.56 & 48 & 3.68 & 51 & 18.91 & 48 \\
\hline Health & 0.62 & 41 & 0.99 & 50 & 4.21 & 48 & 9.58 & 48 & 2.83 & 39 & 18.23 & 46 \\
\hline Environment & 0.25 & 17 & 0.33 & 17 & 0.29 & 3 & 0.77 & 4 & 0.75 & 10 & 2.39 & 6 \\
\hline Total CSR & 1.51 & 100 & 1.99 & 100 & 8.86 & 100 & 19.91 & 100 & 7.26 & 100 & 39.53 & 100 \\
\hline
\end{tabular}

*Amt = Amount

Source: Research result, 2017 


\subsection{Effect of CSR activities on profitability of commercial banks}

\subsubsection{Correlation Analysis}

A correlation matrix was used to determine multi-collinearity among the study variables. Correlation analysis provides a measure of degree of association between variables in a regression model. The result of correlation analysis among the study variables was close to 1.0, this indicated there is a strong correlation between three predictor variables. In a situation where three predictor variables have a correlation coefficient of 1.0, then two of them have to be dropped from the model. As shown in figure 4.1, the three variables are strongly correlated with each other, so the study merged the three independent variables in to one, and took total CSR as the only independent variable for the model. By this reason it used a simple linear regression model instead of multiple linear regression model. The new model became:

$\mathbf{Y}=\boldsymbol{\alpha}+\boldsymbol{\beta} 1 \mathbf{X} 1+\varepsilon$

Where:

$\mathbf{Y}=$ Financial performance measured using net profits before tax (NPBT)

$\boldsymbol{\alpha}=$ Constant

$\mathbf{X 1}=$ Investment in CSR activities

$\boldsymbol{\beta 1}=$ Regression Coefficients for independent variables

$\varepsilon=$ error term

Investment on CSR activities considered only monetary expenses towards social course. Net profits before taxes (NPBT) were used to measure financial performance.

\subsubsection{Regression Analysis}

The study used regression analysis. It included CSR activities as independent variables and NPBT as dependent variable. Linear regression was used to find the effect of education CSR, health CSR and environment CSR activities on financial performance of commercial banks at 5\% level of significance by using STATA 12.

\begin{tabular}{|c|c|c|c|c|c|c|}
\hline \multicolumn{3}{|c|}{ Table 4. Regression Analysis } & & & & \\
\hline & & & & & $\begin{array}{l}\text { Number of Observations } \\
=55\end{array}$ & \\
\hline & & & & & $\begin{array}{l}\text { Wald } \\
=32.73\end{array}$ & \\
\hline & & & & & $\begin{array}{l}\text { Prob }>\text { Chi } 2 \\
=0.0000\end{array}$ & \\
\hline NPBT & Coef. & $\begin{array}{l}\text { Robust } \\
\text { Std.Error }\end{array}$ & $\mathrm{Z}$ & $\mathrm{P}>|\mathrm{Z}|$ & level $\left[\begin{array}{ll}{[95 \%} & \text { Confidence }\end{array}\right.$ & \\
\hline CSR & 59.96944 & 10.48287 & 5.72 & 0.000 & 39.42339 & 80.51549 \\
\hline cons & $312,000,000$ & $75,500,000$ & 4.14 & 0.000 & $164,000,000$ & $460,000,000$ \\
\hline $\begin{array}{l}\text { Sigma } \\
\mathrm{u}\end{array}$ & $176,300,000$ & & & & & \\
\hline $\begin{array}{l}\text { Sigma } \\
\mathrm{e}\end{array}$ & 83876172 & & & & & \\
\hline rho & 0.81539363 & $\begin{array}{l}\text { (fraction of varaince } \\
\text { due to } \mathrm{u} \text { i) }\end{array}$ & & & & \\
\hline
\end{tabular}

Source: Research Results 2017

The findings indicated a p-value of 0.000 which is less than the 0.05 even less than $1 \%$ level of significance. This is an indication that there is a significant relationship between independent variable (CSR activities) and dependent variable (NPBT). The result of probability of chi square which was 0.0000 indicated there is at least one explanatory variable that significantly determines the dependent variable. As the result the model was fit and powerful for prediction. It is therefore reasonable to state that CSR helps to 
improve bank's financial performance and that the model below can be used to fairly determine the effect of CSR activities on financial performance of a commercial banks during the period 2012 to 2016 .

The other study findings were that $\alpha=312,000,000$ and $\beta 1=59.96944$ suggesting that CSR had a positive and direct effect on firm's financial performance. The regression coefficient illustrated that even if a commercial bank did not invest or engage in CSR, it would generate a profit of ETB 312,000,000. The model also showed that, for every ETB increase in CSR investment, bank's NPBT will increase by ETB 59.96944. Therefore, a model of one predictor variable (CSR activities) can be used in forecasting financial performance of commercial banks in Ethiopia for the period 2012 to 2016 . Mathematically the model took the following form:

NPBT $=312,000,000+59.96944 \mathbf{X}$ CSR activities

\section{CONCLUSIONS AND RECOMMENDATIONS}

\subsection{Summary}

The study targeted 17 commercial banks in Ethiopia, and the response rate was $65 \%(\mathrm{n}=11)$. The banks under study were Abay Bank Share Company (AB), Addis International Bank Share Company (ADIB), Awash International Bank (AIB), Bank of Abyssinia Share Company (BOA), Cooperative Bank of Oromia Share Company (CBO), Dashen Bank Share Company (DB), Lion International Bank Share Company (LIB), Oromia International Bank Share Company (OIB), United Bank Share Company (UB), Wegagen Bank Share Company (WB) and Zemen Bank Share Company (ZB). The study aimed investigating effects of CSR activities on banks' performance in financial perspective. Initially the study focused on education CSR activities, health CSR activities and environment CSR activities as independent variables. Financial performance, which was measured using NPBT, was dependent variable of the study. The stakeholder theory, theory of social costs, agency theory and relational theory were used to explain the relation between CSR and banks' financial performance. The study used tables, correlation and regression analysis to analyze collected data.

The descriptive analysis results found that the amount spent on CSR activities by commercial banks in Ethiopia increased for the consecutive four years, but it decreased on the fifth year irrespective of the increasing trend of their NPBT for the whole period under study. The overall share of CSR from NPBT for five Years for all sample banks was $0.20 \%$. The share of education CSR for the five years held $48 \%$ from the total CSR followed by health and environment which constituted $46 \%$ and $6 \%$ respectively. From the above facts we can understand that Ethiopian Commercial banks mostly engage in education CSR activities, followed by health CSR and environment CSR activities.

From the regression model which found a significant positive relationship between CSR and banks profitability, the study found p-value of 0.000 which is less than the 0.05 level of significance. This is an indication that there is a significant relationship between independent and dependent variable. The result of probability of chi square which was 0.0000 indicated there is at least one explanatory variable that significantly determines the dependent variable. As the result the model was fit and powerful for prediction. The other study findings was $\alpha=312,000,000$, suggesting that if a commercial bank did not invest or engage in CSR activities, it would generate a profit of ETB 312,000,000. The model output of $\beta 1=59.96944$ demonstrated that for every ETB increase in CSR activities, bank's NPBT will increase by ETB 59.96944.

The findings of this study agree with those of Okoth (2012) only that this study reveals that CSR improves financial performance of all commercial banks irrespective of their size. The study fully supports the findings of Kipruto (2014)), and those of Gathungu and Ratemo (2013); Odetayo, Adeyemi and Sajuyigbe (2014); Alawiye-Adams and Afolabi (2014), and Ongolo (2012). CSR enables a firm to penetrate the market, remain competitive in a stiff and volatile market and generate profits for a foreseeable future. Commercial banks that started as small have had their profitability improve over a long period to the extent that they are outshining their "large" counterparts. Banks that have reported highest profits have highest Strategic CSR investment compared to those that report very low profits.

This study's findings deviate from the findings of Kotler (2012) that indicated social pressures forced organizations to become socially responsible. Response to social pressures leads to poor profitability in the short-term and long-term.

\subsection{Conclusion and Recommendation}

The study intended to determine the effect that CSR has on financial performance of commercial banks in 
Ethiopia. The researcher used descriptive research design, correlation and a regression analysis and found that CSR has a positive and significant effect on financial performance. This study concludes that CSR is vital for the success of a commercial bank since it helps to improve financial performance. It is, therefore, a noble practice for commercial banks to engage in CSR as part of their operating activities and set aside funds annually towards a social course. CSR should therefore be considered as part of daily operating activities and that for a firm to grow and realize its dreams, it has to engage itself morally and commit itself at improving the society's social and living standards.

The study has established that the amount spend on CSR differed significantly from one bank to the other. Although the study did not establish how the banks determine the amount to be spend on CSR, the amount set aside for CSR by each bank may be attributed to the fact that each bank differs in how it implements corporate social responsibility and that the differences depend on such factors as the specific bank's size, the bank's business culture, stakeholder demands, and how historically progressive the bank is in engaging CSR. However, for successful implementation, law should be enacted that will fix minimum percentage out of profit of organizations' that should spend on corporate social responsibility.

The study reveals that highly profitable commercial banks have heavily invested in CSR activities. Being a good corporate citizen attracts more depositors who are loyal hence guarantee availability of more funds to invest in wider CSR practices and projects. Therefore, commercial institutions should operate outside their normal business activities to support the community and generate a huge amount of profit.

The study found that CSR is good for the financial performance of all commercial institution. For this reason, the researcher recommends that institutions should partner with other institutions that offer varying services to jointly invest in common CSR activities as doing so leads to cost reduction while achieving similar goals. Commercial banks can be partner with telecommunication industries, manufacturing industries, commercial academic institutions or hospitals to spearhead similar CSR objectives.

Finally, since the study revealed that investment on CSR activities is vital for commercial banks in Ethiopia, it recommends that the policy makers in the banking industry should develop strategic policies that would enhance CSR practice of commercial banks while doing their activities.

\section{REFERENCE}

1. Alawiye-Adams, A. A., \& Afolabi, B. (2014). Effects of Corporate Social Responsibility Organizational Performance: Evidence from Nigeria. Available at SSRN 2492864

2. A.Odetayo, Z. Adeyemi and S. Sajuyigbe, (2014) "Impact of Corporate Social Responsibility on Profitability of Nigerian Banks", International Journal of Academic Research Social Sciences, Vol. 4, No. 8 ISSN: 2222-6990.

3. Arya, B., \& Zhang, G. (2009). "Institutional reforms and investor reactions to CSR Announcements: evidence from an emerging economy". Journal of Management Studies, 46(7),1089-1112.

4. Carroll, A. B. (1991). "The pyramid of corporate social responsibility: Toward the moral management of organizational stakeholders". Business Horizons, 39-48.

5. Eilbert, H. \& Parket, I. R. (1973). "The practice of business: The current status of corporate social responsibility". Business Horizons, 16(4), 5-14.

6. Gathungu, J. M. \& Ratemo, N. Z. (2013). “An Assessment of the Impact of Corporate Social Responsibility on the Strategic Intent at Standard Chartered Bank Kenya Limited".International Journal of Education and Research, 1(5) 1-16.

7. Kuprito, D. (2014). "The effect of Corporate Social Responsibility on Financial Performance of commercial banks in Kenya": Myth, Reality or Empty Rhetoric. The African Finance Journal, 9, 53-68.

8. M. Rahman and F. Iqbal (2013), "Corporate Social Responsibility Practices and Private Commercial Banks", International Journal of Science and Research, Volume 2 Issue 1 India Online ISSN: 2319-7064

9. National Bank of Ethiopia (2017), CSR investment by commercial banks in Ethiopia from 2011-2016 and financial statement data base, https://www.nbe.gov.et/publications/annualreport.ht $\mathrm{ml}$ [Accessed on 27.09.2017]

10. Okiro K., Omoro N. \& Kinyua H. (2013), "Investment in Corporate Social Responsibility and 
International Journal of Trend in Scientific Research and Development (IJTSRD) ISSN: 2456-6470

Sustained Growth in Commercial Banks in Kenya", Journal of Emerging Issues in Economics, Finance and Banking. An Online International Monthly Journal, 3(2), 1057-1064.

11. Owen, L., O’dwyer, B. (2008), “Corporate Social Responsibility: The Reporting and Assurance Dimension", The Oxford Handbook of Corporate Social Responsibility. New York: Oxford.

12. Tjia O, Setiawati L, 2012. "Effect of CSR Disclosure to Value of the Firm: Study for Banking Industry in Indonesia", World Journal of Social Sciences, 2: 169 - 178.

13. Werther, W. B., \& Chandler, D. (2010).Strategic corporate social responsibility: Stakeholders in a global environment (2nd edition.). Thousand Oaks, CA: Sage Publications, Inc.

1. Yeung,( 2011), 'The Role of Banks in Corporate Social Responsibility', Journal of Applied Economics and Business Research, 1(2), pp. 103115 